\title{
THE RELATION BETWEEN SMOKING HABITS AND PHYSIQUE, RESPIRATORY SYMPTOMS, VENTILATORY FUNCTION, AND RADIOLOGICAL PNEUMOCONIOSIS AMONGST COAL WORKERS AT THREE SCOTTISH COLLIERIES
}

\author{
BY
}

\author{
J. R. ASHFORD, SUSANNAH BROWN, D. P. DUFFIELD, C. S. SMITH, AND J. W. J. FAY \\ Pneumoconiosis Field Research, National Coal Board
}

Smoking has for some time been strongly suspected of being a major aetiological factor in chronic bronchitis. Confirmatory evidence has accrued from many epidemiological studies involving widely different populations. Abbott, Hopkins, Van Fleit, and Robinson (1953) found that, in 294 hospital patients with emphysema and cough, tobacco smoking could be incriminated as an aetiological factor in about two-thirds of the cases, and Palmer (1954) confirmed these findings, again on a hospital population.

The use of hospital populations in epidemiological studies is open to the danger of selection, with consequent doubts about the general applicability of the results, but the work of Abbott and Palmer and their collaborators cited above has been confirmed in studies of representative samples of the general population. Clifton (1956), in a study of rural dwellers and of workers in heavy industry in Sheffield, found smoking to be an important factor in the prevalence of chronic bronchitis in these two populations. Ogilvie and Newell (1957), in their Newcastle survey, confirmed the association between smoking and chronic bronchitis, but were unable to relate the prevalence of the disease to the amount of tobacco smoked. Brown, McKeown, and Whitfield (1957), in a study of 1,062 men aged 60-69 years, and Higgins, Oldham, Cochrane, and Gilson (1956), in their Leigh survey, agreed with these findings.

Less information is available about the effects of smoking on ventilatory function. Franklin (1958) found that heavy smokers recorded lower flow rates in maximal forced expirations than did light smokers and non-smokers, this happening frequently in the absence of any pulmonary abnormality. Eich, Gilbert, and Auchincloss (1957), investigating experimentally the effects of cigarette smoking, found, in emphysematous patients, that there was an increase in airways resistance after smoking one cigarette, but Bickerman and Barach (1954) found no significant effect after their subjects had smoked three cigarettes. Higgins (1959), in a study of 734 men aged 25 to 64 years randomly selected from urban and rural populations, recorded a higher indirect maximum breathing capacity (M.B.C.) for non-smokers than for smokers, but found "no significant downward trend with increasing tobacco consumption among the smokers". Fletcher, Elmes, Fairbairn, and Wood (1959) came to the same conclusion about a group of London postmen, aged 40 to 59 years. However, Higgins, in a study with other workers of a population of mixed occupations in Staveley, Derbyshire, found that "the heavier smokers recorded a lower mean M.B.C. than the lighter" (Higgins, Cochrane Gilson, and Wood, 1959).

As part of the National Coal Board's Pneumoconiosis Field Research (Fay, 1957; Fay and Rae, 1959; Rogan, Ashford, Chapman, Duffield, Fay, and Rae, 1961), periodic medical surveys, including the measurement of ventilatory function and physique and the assessment of radiological pneumoconiosis, respiratory symptoms, and smoking habits, are carried out on the underground and surface workers at a sample of 25 collieries distributed throughout the main British coalfields. The data collected on these surveys provide a convenient opportunity to examine the relation between smoking habits and these other factors in complete working populations, and this paper is concerned with the results obtained at the first three collieries in Scotland at which the necessary measurements have been made. 


\section{Data Available}

The three collieries under consideration are situated respectively in Ayrshire, Lanarkshire, and the Lothians. At each survey more than 90 per cent. of the underground and surface workers on the colliery books were examined and information is available for a total of 4,014 men.

The medical examination can be divided into the following four main components:

(i) The taking of a $14^{\prime \prime} \times 14^{\prime \prime}$ chest X-ray film which was subsequently read in accordance with the I.L.O. classification (I.L.O., 1953).

(ii) The forced expiratory volume measured in litres in the first second (F.E.V. 1 sec.), using the Gaensler apparatus (Gaensler, 1951), as modified by the Medical Research Council Pneumoconiosis Research Unit (Carpenter, Cochrane, Gilson, and Higgins, 1956). Four sets of readings were recorded, of which the first was discarded to take account of the "learning" effect (Ashford, Forwell, and Routledge, 1960).

(iii) The measurement of sitting height, standing height and weight.

(iv) The application of a short respiratory symptoms questionnaire, including questions about smoking habits (Appendix).

At all three collieries the data were collected by the same (No. 1) X-ray Unit, under Dr. S. Rae.

Each man presenting himself for examination was asked the following questions about his smoking habits:

(a) "Do you smoke?"

(If the answer to (a) was "Yes")

(b) "How many cigarettes do you smoke each day?"

(c) "How much pipe tobacco do you smoke each week?"

(If the answer to (a) was "No")

(d) "Have you ever smoked as much as ten cigarettes a day for 10 years?"

It will be noted that, for the purpose of replying to question $(d)$, "having ever smoked" was interpreted as having smoked at least ten cigarettes per day (or the equivalent in pipe tobacco) for as long as 10 years or the equivalent. This definition was deliberately chosen to be more rigorous than that employed by Doll and Hill (1950), who regard "one cigarette per day for 1 year" as being a sufficient "qualifying" period. However, it has since been found in special inquiries amongst the working populations at three collieries (Rae, 1960) that in practice this difference in definition has only a small effect on the proportion of men classed as "non-smoker". Out of a total of some 4,500 men, there was a change in the smoking classification (from "non-smoker" to "ex-smoker") of only 1.5 per cent. when the criterion was altered from "ten cigarettes per day for 10 years" to "one cigarette per day for 1 year". In view of this small difference and in order to remove the apparent inconsistency between the definitions of "smoker" and "ex-smoker", the more commonly accepted definition of "one cigarette per day for 1 year" has been adopted for subsequent medical surveys.

It will be noted that, apart from question $(d)$, the inquiry was confined to current smoking habits. The difficulty of obtaining an accurate and detailed record of a man's smoking history has been emphasized by Todd and Laws (1958), and it was considered that little further information would be gained by attempting to do so in this inquiry.

The general trends shown by the results obtained at the three collieries were similar and all the available data have therefore been taken together in the subsequent analysis.

\section{Summary of Smoking Habits}

According to their answers to questions $(a)$ and $(d)$ the men examined were classified as "Smokers" ['Yes' to $(a)$ ], "Ex-smokers" ['No' to (a), 'Yes' to $(d)$ ], or "Non-smokers" ['No' to $(a)$ and $(d)$ ]. Thus the use of the term "non-smoker" in this paper is not strictly consistent with the practice of other authors (e.g. Todd, 1957), who apply the term to all men who did not smoke at the time the questionnaire was asked, whatever their past smoking history. According to their answers to questions $(b)$ and $(c)$, the smokers were further subdivided into "Cigarettes only", "Pipe only", and "Cigarettes and pipe"*. The amount of tobacco consumed has been expressed in terms of "equivalent cigarettes per day", one ounce of pipe tobacco being taken as equivalent to 28 cigarettes.

The smoking habits recorded at the three collieries are summarized in Table I and illustrated by Fig. 1(a) (overleaf), where the results have been subdivided in terms of six age groups-Under 21, 21-30, 31-40, $41-50,51-60$, and Over 60 years. Approximately 80 per cent. of the men examined were classed as smokers, 17 per cent. as non-smokers, and 3 per cent. as ex-smokers. Under the more commonly accepted definition of ex-smokers, the proportion of men assigned to this group would probably be increased by about $1 \cdot 5$ per cent., with a corresponding

- At the Lothians colliery questions $(b)$ and $(c)$ were modified and it is not possible to obtain a breakdown of the smokers in terms of "cigarettes" and "pipe". 
decrease in the proportion of non-smokers. The proportion of smokers shows very little variation with age. As might be expected on general grounds, the ex-smokers tend to occur most frequently amongst the older age groups.

TABLE I

SUMMARY OF SMOKING HABITS, BY AGE

\begin{tabular}{|c|c|c|c|c|c|c|c|c|}
\hline \multirow{2}{*}{$\underset{\text { (yrs) }}{\text { Age }}$} & \multicolumn{2}{|c|}{ Smokers } & \multicolumn{2}{|c|}{ Non-smokers } & \multicolumn{2}{|c|}{ Ex-smokers } & \multicolumn{2}{|c|}{ Total } \\
\hline & No. & $\begin{array}{c}\text { Per } \\
\text { cent. }\end{array}$ & No. & $\begin{array}{c}\text { Per } \\
\text { cent. }\end{array}$ & No. & $\begin{array}{c}\text { Per } \\
\text { cent. }\end{array}$ & No. & $\begin{array}{r}\text { Per } \\
\text { cent }\end{array}$ \\
\hline $\begin{array}{c}\text { Under } 21 \\
21-30 \\
31-40 \\
41-50 \\
51-60 \\
\text { Over } 60\end{array}$ & $\begin{array}{l}280 \\
555 \\
777 \\
755 \\
610 \\
237\end{array}$ & $\begin{array}{l}73 \cdot 1 \\
75 \cdot 1 \\
82 \cdot 7 \\
83 \cdot 2 \\
81 \cdot 7 \\
79 \cdot 5\end{array}$ & $\begin{array}{r}103 \\
182 \\
138 \\
110 \\
102 \\
42\end{array}$ & $\begin{array}{l}26 \cdot 9 \\
24 \cdot 6 \\
14 \cdot 7 \\
12 \cdot 1 \\
13 \cdot 7 \\
14 \cdot 1\end{array}$ & $\begin{array}{r}0 \\
2 \\
25 \\
42 \\
35 \\
19\end{array}$ & $\begin{array}{l}0 \cdot 0 \\
0 \cdot 3 \\
2 \cdot 7 \\
4 \cdot 6 \\
4 \cdot 7 \\
6 \cdot 4\end{array}$ & $\begin{array}{l}383 \\
739 \\
940 \\
907 \\
747 \\
298\end{array}$ & $\begin{array}{l}100 \\
100 \\
100 \\
100 \\
100 \\
100\end{array}$ \\
\hline All & 3,214 & $80 \cdot 1$ & 677 & $16 \cdot 9$ & 123 & $3 \cdot 1$ & 4,014 & 100 \\
\hline
\end{tabular}

Table II, which refers only to the Ayrshire and Lanarkshire collieries, omitting the Lothians, shows that some 84 per cent. of the smokers were classed as "cigarettes only", 11 per cent. as "pipe only", and 5 per cent. as "cigarettes and pipe". Fig. $1(b)$ shows that the proportion of cigarette smokers decreases steadily with age, from 100 per cent. for the Under 21-year age group to less than 50 per cent. for the Over 60-year age group. There is a corresponding increase with age in the proportion of pipe smokers and, to a lesser extent, in the proportion of men who - smoke both cigarettes and pipe.

TABLE II

SUB-DIVISION OF SMOKERS, BY SMOKING HABITS AND AGE

(excluding Lothians Colliery)

\begin{tabular}{|c|c|c|c|c|c|c|c|c|}
\hline \multirow{2}{*}{$\begin{array}{l}\text { Age } \\
\text { Group } \\
\text { (yrs) }\end{array}$} & \multicolumn{2}{|c|}{$\begin{array}{l}\text { Cigarettes } \\
\text { (only) }\end{array}$} & \multicolumn{2}{|c|}{ Pipe (only) } & \multicolumn{2}{|c|}{$\begin{array}{l}\text { Cigarettes } \\
\text { and Pipe }\end{array}$} & \multicolumn{2}{|c|}{ Total } \\
\hline & No. & $\begin{array}{l}\text { Per } \\
\text { cent. }\end{array}$ & No. & $\begin{array}{l}\text { Per } \\
\text { cent. }\end{array}$ & No. & $\begin{array}{l}\text { Per } \\
\text { cent. }\end{array}$ & No. & $\begin{array}{l}\text { Per } \\
\text { cent }\end{array}$ \\
\hline $\begin{array}{c}\text { Under } 21 \\
21-30 \\
31-40 \\
41-50 \\
51-60 \\
\text { Over 60 }\end{array}$ & $\begin{array}{r}149 \\
295 \\
338 \\
368 \\
292 \\
62\end{array}$ & $\begin{array}{r}100 \cdot 0 \\
99 \cdot 0 \\
90 \cdot 6 \\
82 \cdot 1 \\
72 \cdot 8 \\
48 \cdot 8\end{array}$ & $\begin{array}{r}0 \\
2 \\
23 \\
52 \\
75 \\
50\end{array}$ & $\begin{array}{r}0.0 \\
0.7 \\
6.2 \\
11.6 \\
18.7 \\
39 \cdot 4\end{array}$ & $\begin{array}{r}0 \\
1 \\
12 \\
28 \\
34 \\
15\end{array}$ & $\begin{array}{r}0 \cdot 0 \\
0 \cdot 3 \\
3 \cdot 2 \\
6 \cdot 2 \\
8 \cdot 5 \\
11 \cdot 8\end{array}$ & $\begin{array}{l}149 \\
298 \\
373 \\
448 \\
401 \\
127\end{array}$ & $\begin{array}{l}100 \\
100 \\
100 \\
100 \\
100 \\
100\end{array}$ \\
\hline All & 1,504 & $83 \cdot 7$ & 202 & $11 \cdot 2$ & 90 & $5 \cdot 0$ & 1,796 & 100 \\
\hline
\end{tabular}

Details of the average tobacco consumption at the Ayrshire and Lanarkshire collieries are given in Table III. The average amount smoked by the cigarette smokers is approximately fifteen cigarettes per day, compared with the equivalent of just over ten per day for the pipe smokers and 25 per day for those who smoke both cigarettes and pipe.

TABLE III

AVERAGE TOBACCO CONSUMPTION BY SMOKING HABITS AND AGE

(excluding Lothians Colliery)

Average No. of Cigarettes per Day (or Equivalent)

\begin{tabular}{|c|c|c|c|c|}
\hline$\underset{\text { (yrs) }}{\text { Age Group }}$ & $\begin{array}{l}\text { Cigarettes } \\
\text { (only) }\end{array}$ & Pipe (only) & $\begin{array}{l}\text { Cigarettes } \\
\text { and Pipe }\end{array}$ & $\underset{\text { Smokers }}{\text { All }}$ \\
\hline $\begin{array}{c}\text { Under } 21 \\
21-30 \\
31-40 \\
41-50 \\
51-60 \\
\text { Over } 60\end{array}$ & $\begin{array}{l}10 \cdot 9 \\
15 \cdot 3 \\
16 \cdot 4 \\
16 \cdot 2 \\
14 \cdot 9 \\
13 \cdot 8\end{array}$ & $\begin{array}{r}\overline{5 \cdot 5} \\
13 \cdot 1 \\
10 \cdot 9 \\
10 \cdot 7 \\
9 \cdot 0\end{array}$ & $\begin{array}{l}\overline{15 \cdot 5} \\
22 \cdot 8 \\
27 \cdot 2 \\
25 \cdot 5 \\
21 \cdot 8\end{array}$ & $\begin{array}{l}10 \cdot 9 \\
15 \cdot 3 \\
16 \cdot 4 \\
16 \cdot 3 \\
15 \cdot 0 \\
12 \cdot 9\end{array}$ \\
\hline All & $15 \cdot 2$ & $10 \cdot 5$ & $25 \cdot 0$ & $15 \cdot 2$ \\
\hline
\end{tabular}

Fig. 2 (overleaf) shows that, amongst the younger men, the amount of tobacco consumed tends to increase with increasing age, reaching a maximum of the equivalent of just over sixteen cigarettes per day for the 31 to 40 and 41 to 50-year age groups, and then declining to just less than thirteen cigarettes per day for the Over 60-year age group. A similar trend is noted when each of the types of smoker is considered separately.

These results are, in general, in fairly good agreement with the findings of Todd (1957), who carried out sample survey inquiries amongst the general population based on a similar questionnaire. In comparison with Todd's figures for males in Great Britain in 1956 ( see Figs 1 and 2), the proportion of smokers in the three colliery populations is slightly higher for all age groups. The proportion of smokers who smoke both cigarettes and pipe is slightly lower than the national average and the proportion who smoke cigarettes only is slightly higher. In all age groups the amount of tobacco consumed by the smokers is slightly less than Todd's national average figures.

\section{PhysiQue}

In the course of the medical surveys, measurements have been made of the weight, standing height, and sitting height of each man presenting himself for examination. It has been found that standing height provides no further information about ventilatory function additional to that which is provided by sitting height, and for this reason weight and sitting height only have been considered in the subsequent analysis. The average weight corresponding to each 
(a) ALL MEN

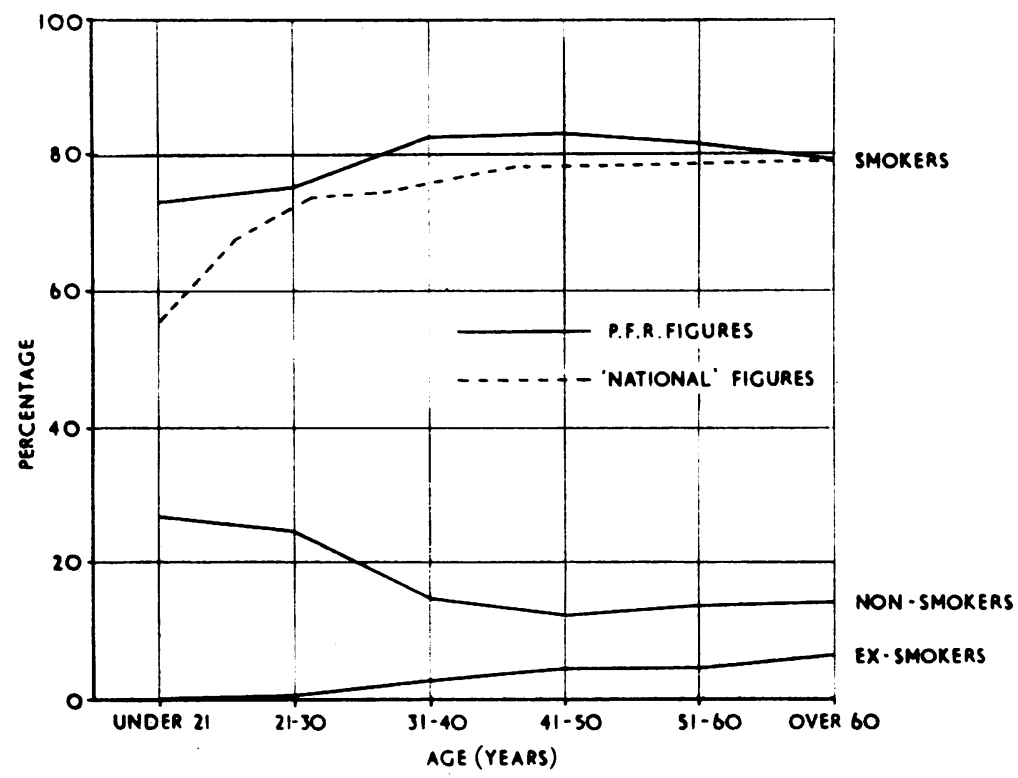

(b) SMOKERS ONLY (excluding Lothions Colliery)

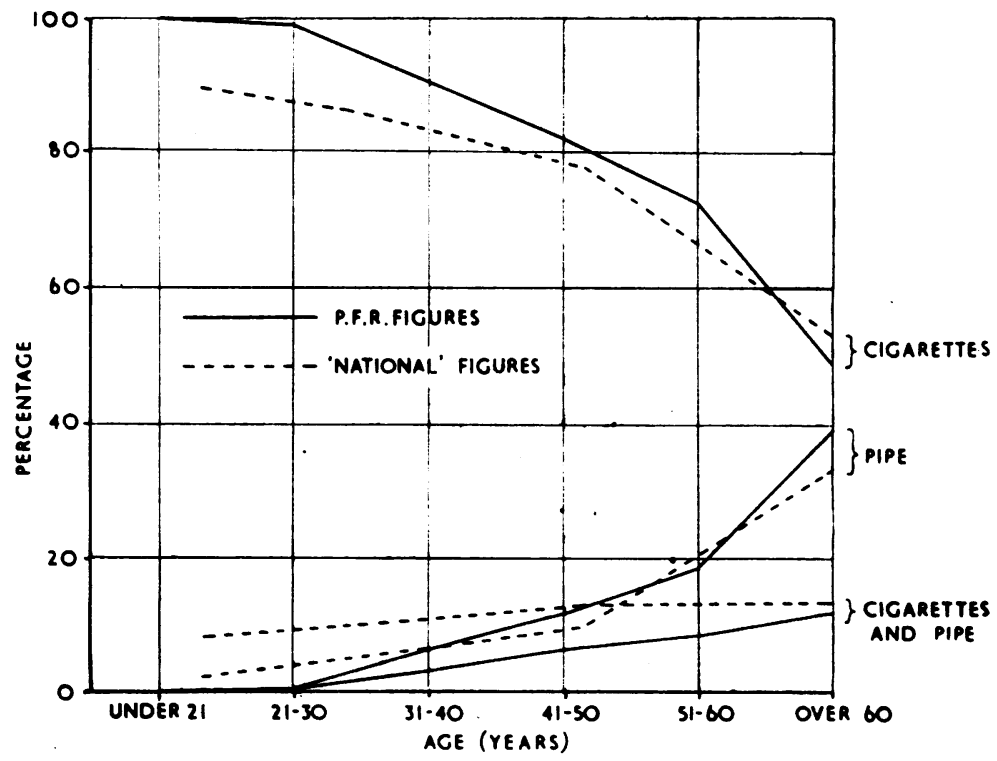

Fig. 1.-Smoking habits, by age. 


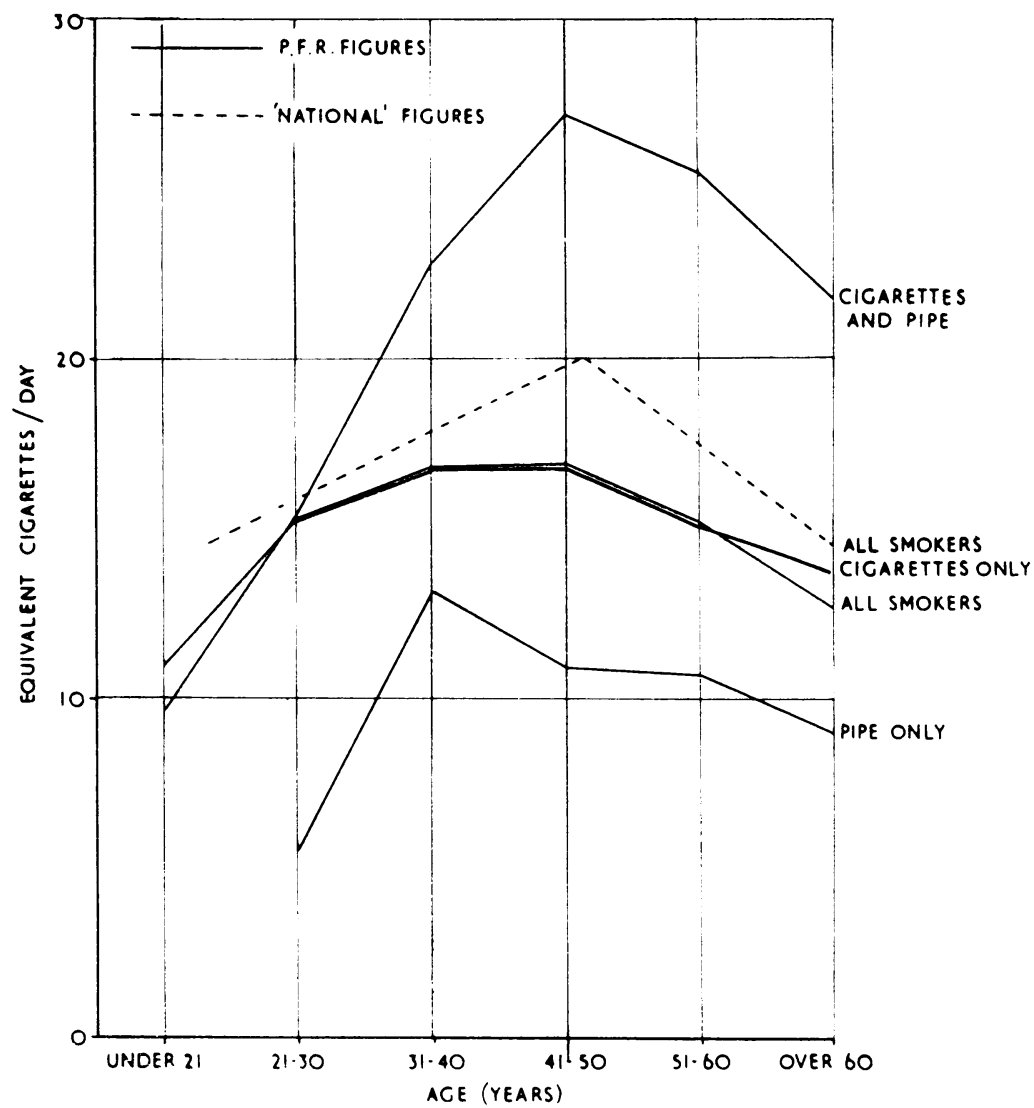

FIG. 2.-Amount of tobacco consumed, by age, at the Ayrshire and Lanarkshire collieries

of the six age groups has been calculated for the smokers, ex-smokers, and non-smokers at the three collieries. The results for smokers at the Ayrshire and Lanarkshire collieries have been further subdivided in terms of the three smoking types and also into three classes according to the amount of tobacco smoked. Details are given in Table IV, which shows that the non-smokers and ex-smokers tend to be heavier than the smokers, the average difference being of the order of 3 to $4 \mathrm{~kg}$. Age for age there is a tendency amongst the smokers for the weight of the men who consume the most tobacco to be above the

TABLE IV

AVERAGE WEIGHT (kg.), BY SMOKING HABITS AND AGE

\begin{tabular}{|c|c|c|c|c|c|c|c|c|c|}
\hline \multirow{3}{*}{$\underset{\text { (yrs) }}{\text { Age Group }}$} & \multicolumn{7}{|c|}{ Smokers } & \multirow{3}{*}{$\begin{array}{l}\text { Non- } \\
\text { smokers }\end{array}$} & \multirow{3}{*}{$\begin{array}{c}\text { Ex- } \\
\text { smokers }\end{array}$} \\
\hline & \multicolumn{3}{|c|}{$\begin{array}{l}\text { Type } \\
\text { [All quantities] }\end{array}$} & \multicolumn{3}{|c|}{$\begin{array}{l}\text { Consumption (equivalent cigs/day) } \\
\text { [All types] }\end{array}$} & \multirow{2}{*}{$\underset{\text { Smokers }}{\text { All }}$} & & \\
\hline & $\begin{array}{l}\text { Cigarettes* } \\
\text { (only) }\end{array}$ & Pipe* (only) & $\begin{array}{l}\text { Cigarettes } \\
\text { and Pipe }\end{array}$ & $1-10^{*}$ & $11-20^{*}$ & Over $20^{*}$ & & & \\
\hline $\begin{array}{c}\text { Under } 21 \\
21-30 \\
31-40 \\
41-50 \\
51-60 \\
\text { Over } 60\end{array}$ & $\begin{array}{l}64 \cdot 0 \\
70 \cdot 0 \\
72 \cdot 9 \\
72 \cdot 1 \\
70 \cdot 8 \\
69 \cdot 8\end{array}$ & $\begin{array}{l}7 \overline{4} \cdot 0 \\
79 \cdot 1 \\
73 \cdot 1 \\
75 \cdot 3 \\
77 \cdot 0\end{array}$ & $\begin{array}{l}-\overline{1} \cdot 7 \\
78 \cdot 1 \\
75 \cdot 3 \\
74 \cdot 0 \\
76 \cdot 9\end{array}$ & $\begin{array}{l}62 \cdot 6 \\
69 \cdot 4 \\
74 \cdot 7 \\
71 \cdot 0 \\
71 \cdot 5 \\
74 \cdot 4\end{array}$ & $\begin{array}{l}65 \cdot 8 \\
69 \cdot 3 \\
72 \cdot 7 \\
72 \cdot 5 \\
71 \cdot 5 \\
72 \cdot 7\end{array}$ & $\begin{array}{l}66 \cdot 8 \\
75 \cdot 0 \\
75 \cdot 0 \\
73 \cdot 3 \\
74 \cdot 2 \\
72 \cdot 3\end{array}$ & $\begin{array}{l}64 \cdot 4 \\
70 \cdot 9 \\
73 \cdot 7 \\
72 \cdot 7 \\
71 \cdot 8 \\
72 \cdot 3\end{array}$ & $\begin{array}{l}66 \cdot 2 \\
75 \cdot 0 \\
76 \cdot 4 \\
76 \cdot 9 \\
76 \cdot 4 \\
77 \cdot 0\end{array}$ & $\begin{array}{l}7 \overline{71} \cdot 9 \\
75.9 \\
77.4 \\
73 \cdot 8 \\
76.8\end{array}$ \\
\hline All & $70 \cdot 7$ & $75 \cdot 5$ & $75 \cdot 3$ & $70 \cdot 3$ & $71 \cdot 4$ & $74 \cdot 0$ & $71 \cdot 7$ & $74 \cdot 6$ & 75.9 \\
\hline
\end{tabular}


average although it is still not as high as for nonsmokers or ex-smokers. However, when the type of smoking is considered, the cigarette smokers are, on average, about $5 \mathrm{~kg}$. lighter than the pipe smokers and those smoking both cigarettes and pipe in all age groups. These latter smoking types are almost as heavy as the ex-smokers and very slightly heavier than the non-smokers.

The relation between smoking habits and sitting height is illustrated in Table V. In general, the average sitting height of the non-smokers and exsmokers tends to be about $0.5 \mathrm{~cm}$. greater than that of the smokers of the same age, and statistical tests show that this difference is significant. When the smokers are considered, there is a tendency for the sitting height of the men with the highest consump- tion of tobacco to be above the average for smokers generally, and, in fact, slightly greater than that of the non-smokers. The average sitting height of the pipe smokers does not differ consistently from that of the cigarette smokers of the same age, whereas that of the men smoking both cigarettes and pipe tends to be slightly higher.

\section{RESPIRATORY SYMPTOMS}

On the basis of the man's replies to the questionnaire an assessment was made of whether or not he had "respiratory symptoms" [i.e. bronchitis and/or asthma (Appendix)].

The results obtained at the three collieries are shown in Table VI (overleaf), and the general trends in Fig. 3, which indicates that the prevalence of the

TABLE V

AVERAGE SITTING HEIGHT (cm.), BY SMOKING HABITS AND AGE

\begin{tabular}{|c|c|c|c|c|c|c|c|c|c|}
\hline \multirow{3}{*}{$\underset{\text { (yrs) }}{\text { Age Group }}$} & \multicolumn{7}{|c|}{ Smokers } & \multirow{3}{*}{$\begin{array}{c}\text { Non- } \\
\text { smokers }\end{array}$} & \multirow{3}{*}{$\begin{array}{c}\text { Ex- } \\
\text { smokers }\end{array}$} \\
\hline & \multicolumn{3}{|c|}{$\begin{array}{l}\text { Type } \\
\text { [All quantities] }\end{array}$} & \multicolumn{3}{|c|}{$\begin{array}{l}\text { Consumption (equivalent cigs/day) } \\
\text { [All types] }\end{array}$} & \multirow{2}{*}{$\underset{\text { Smokers }}{\text { All }}$} & & \\
\hline & $\begin{array}{l}\text { Cigarettes* } \\
\text { (only) }\end{array}$ & Pipe* (only) & $\begin{array}{l}\text { Cigarettes* } \\
\text { and Pipe }\end{array}$ & $1-10^{*}$ & $11-20^{*}$ & Over $20^{*}$ & & & \\
\hline $\begin{array}{c}\text { Under } 21 \\
21-30 \\
31-40 \\
41-50 \\
51-60 \\
\text { Over } 60\end{array}$ & $\begin{array}{l}88 \cdot 8 \\
90 \cdot 5 \\
90 \cdot 1 \\
89 \cdot 9 \\
88 \cdot 7 \\
87 \cdot 9\end{array}$ & $\begin{array}{l}9 \overline{90 \cdot 5} \\
91 \cdot 3 \\
89 \cdot 2 \\
89 \cdot 1 \\
88 \cdot 2\end{array}$ & $\begin{array}{l}8 \overline{7} \cdot 0 \\
90 \cdot 9 \\
90 \cdot 2 \\
89 \cdot 3 \\
89 \cdot 7\end{array}$ & $\begin{array}{l}88 \cdot 1 \\
89 \cdot 6 \\
90 \cdot 5 \\
89 \cdot 5 \\
88 \cdot 5 \\
87 \cdot 9\end{array}$ & $\begin{array}{l}89 \cdot 9 \\
90 \cdot 6 \\
89 \cdot 9 \\
89 \cdot 9 \\
88 \cdot 8 \\
88 \cdot 3\end{array}$ & $\begin{array}{l}87 \cdot 3 \\
91 \cdot 1 \\
90 \cdot 7 \\
90 \cdot 0 \\
89 \cdot 2 \\
89 \cdot 6\end{array}$ & $\begin{array}{l}88 \cdot 6 \\
90 \cdot 5 \\
90 \cdot 1 \\
89.6 \\
88.9 \\
87 \cdot 7\end{array}$ & $\begin{array}{l}89 \cdot 6 \\
91 \cdot 0 \\
90 \cdot 1 \\
90 \cdot 2 \\
88 \cdot 6 \\
88 \cdot 5\end{array}$ & $\begin{array}{l}8 \overline{87 \cdot 5} \\
90 \cdot 8 \\
90 \cdot 3 \\
89 \cdot 7 \\
88 \cdot 3\end{array}$ \\
\hline All & $89 \cdot 6$ & $89 \cdot 2$ & $89 \cdot 8$ & 88.9 & $89 \cdot 7$ & $90 \cdot 1$ & $89 \cdot 5$ & $90 \cdot 0$ & $89 \cdot 9$ \\
\hline
\end{tabular}

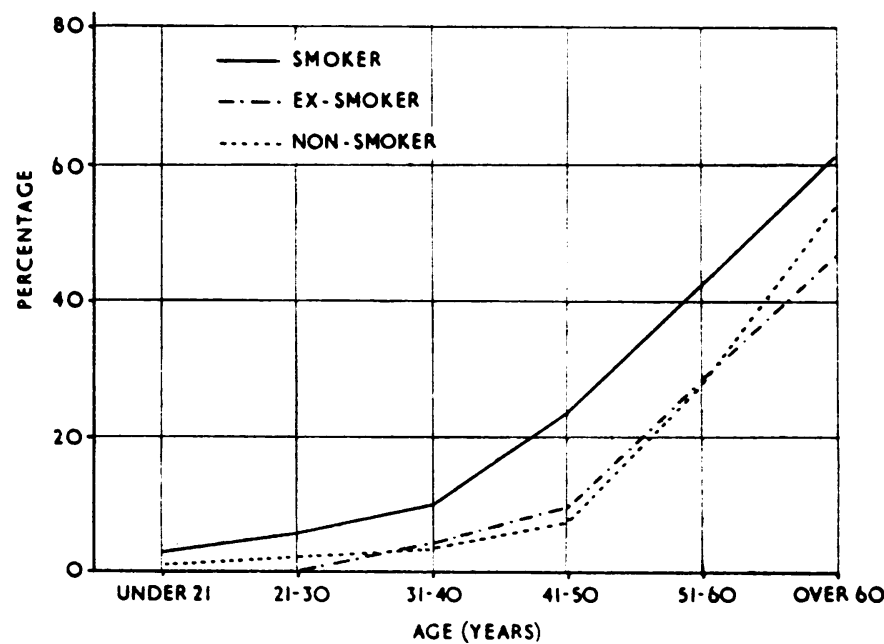

Fig. 3.-Prevalence of respiratory symptoms (per cent.), by age and smoking habits. 
PREVALENCE OF RESPIRATORY SYMPTO $\bar{X}$ SS

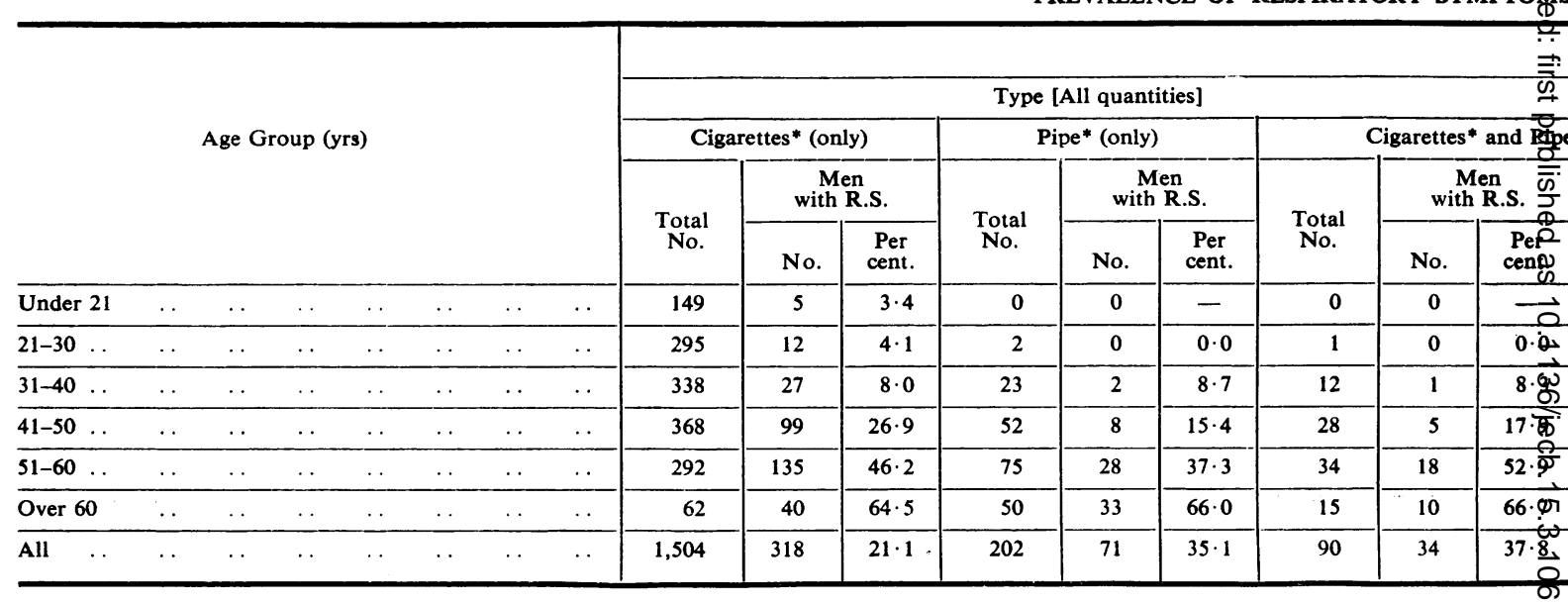

respiratory symptoms complex amongst the smokers is significantly higher than amongst the non-smokers and ex-smokers of the same age. When the smokers are considered separately, however, there is no evidence of any consistent relation between the prevalence of respiratory symptoms and amount of tobacco consumed. In the younger age groups, the lowest prevalence of respiratory symptoms is reported for the lightest smokers, but the reverse applies amongst the older men. Age for age there is no consistent difference in prevalence between the three types of smoker.

\section{Ventilatory Function}

The relation between F.E.V., age and smoking habits at the three collieries is illustrated in Table VII. In all groups there is a marked tendency for F.E.V. to decrease with age. The average F.E.V. of the non-smokers is slightly higher than that of the smokers, and the difference between the two groups is significant. The corresponding figures for the ex-smokers show no consistent pattern. Amongst the smokers, the average F.E.V. bears no consistent relationship to the amount of tobacco consumed or to the type of smoking.

When considering the difference in average F.E.V. between smokers and non-smokers, it must be borne in mind that there are significant differences in physique between the two groups. As it is found that sitting height is positively correlated with F.E.V., it is necessary to make some allowance for this factor as well as for age before any definite conclusions can be drawn. On the other hand, when account is taken of sitting height, there is no consistent relationship between weight and F.E.V. and the effect of weight can therefore safely be ignored. For each colliery separately, calculations were carried out to determine the relation between F.E.V., age, and sitting

TABLE VII

AVERAGE FEV.1 sec. (LITRES), BY SMOKING HABITS AND AGE

\begin{tabular}{|c|c|c|c|c|c|c|c|c|c|}
\hline \multirow{3}{*}{$\underset{\text { (yrs) }}{\text { Age Group }}$} & \multicolumn{7}{|c|}{ Smokers } & \multirow{3}{*}{$\begin{array}{c}\text { Non- } \\
\text { smokers }\end{array}$} & \multirow{3}{*}{$\begin{array}{c}\text { Ex- } \\
\text { smokers }\end{array}$} \\
\hline & \multicolumn{3}{|c|}{$\begin{array}{c}\text { Type } \\
\text { [All quantites] }\end{array}$} & \multicolumn{3}{|c|}{$\begin{array}{l}\text { Consumption (equivalent cigs/day) } \\
\text { [All types] }\end{array}$} & \multirow{2}{*}{$\begin{array}{c}\text { All } \\
\text { Smokers }\end{array}$} & & \\
\hline & $\begin{array}{l}\text { Cigarettes* } \\
\text { (only) }\end{array}$ & Pipe* (only) & $\begin{array}{l}\text { Cigarettes* } \\
\text { and Pipe }\end{array}$ & $1-10^{*}$ & $11-20^{*}$ & Over $20^{*}$ & & & \\
\hline $\begin{array}{c}\text { Under } 21 \\
21-30 \\
31-40 \\
41-50 \\
51-60 \\
\text { Over } 60\end{array}$ & $\begin{array}{l}3 \cdot 87 \\
3 \cdot 87 \\
3 \cdot 39 \\
2 \cdot 88 \\
2 \cdot 35 \\
1 \cdot 98\end{array}$ & $\begin{array}{l}3 \cdot \overline{3} \\
3 \cdot 57 \\
2 \cdot 76 \\
2 \cdot 48 \\
2 \cdot 07\end{array}$ & $\begin{array}{l}2 \cdot-30 \\
3 \cdot 27 \\
2 \cdot 97 \\
2 \cdot 29 \\
2 \cdot 19\end{array}$ & $\begin{array}{l}3 \cdot 74 \\
3 \cdot 83 \\
3.50 \\
2 \cdot 89 \\
2 \cdot 28 \\
1.95\end{array}$ & $\begin{array}{l}4 \cdot 02 \\
3 \cdot 90 \\
3 \cdot 38 \\
2 \cdot 89 \\
2 \cdot 41 \\
2 \cdot 14\end{array}$ & $\begin{array}{l}4 \cdot 17 \\
3 \cdot 72 \\
3 \cdot 36 \\
2 \cdot 80 \\
2 \cdot 37 \\
2 \cdot 03\end{array}$ & $\begin{array}{l}3 \cdot 81 \\
3.84 \\
3.40 \\
2.92 \\
2 \cdot 42 \\
2 \cdot 02\end{array}$ & $\begin{array}{l}4 \cdot 00 \\
3.96 \\
3 \cdot 46 \\
3 \cdot 03 \\
2 \cdot 55 \\
2 \cdot 24\end{array}$ & $\begin{array}{l}3 \cdot 58 \\
3 \cdot 72 \\
2 \cdot 96 \\
2 \cdot 59 \\
2 \cdot 02\end{array}$ \\
\hline All & $3 \cdot 14$ & 2.59 & $2 \cdot 62$ & 2.96 & $3 \cdot 12$ & 2.95 & $3 \cdot 11$ & $3 \cdot 39$ & $2 \cdot 87$ \\
\hline
\end{tabular}

* Excluding Lothians Colliery. 
VI

(R.S.), BY SMOKING HABITS AND AGE

\begin{tabular}{|c|c|c|c|c|c|c|c|c|c|c|c|c|c|c|c|c|c|}
\hline & \multicolumn{2}{|c|}{$\begin{array}{l}\text { ion (equivalen } \\
-10^{*}\end{array}$} & & $1-20^{*}$ & & & ver 20 & & \multicolumn{3}{|c|}{ All Smokers } & \multicolumn{3}{|c|}{ Non-Smokers } & \multicolumn{3}{|c|}{ Ex-Smokers } \\
\hline No. & No. & $\begin{array}{l}\text { Per } \\
\text { cent. }\end{array}$ & $\begin{array}{l}\text { Total } \\
\text { No. }\end{array}$ & No. & $\begin{array}{l}\text { Per } \\
\text { cent. }\end{array}$ & $\begin{array}{l}\text { Total } \\
\text { No. }\end{array}$ & No. & $\begin{array}{c}\text { Per } \\
\text { cent. }\end{array}$ & $\begin{array}{l}\text { Total } \\
\text { No. }\end{array}$ & No. & $\begin{array}{c}\text { Per } \\
\text { cent. }\end{array}$ & $\begin{array}{l}\text { Total } \\
\text { No. }\end{array}$ & No. & $\begin{array}{l}\text { Per } \\
\text { cent. }\end{array}$ & $\begin{array}{l}\text { Total } \\
\text { No. }\end{array}$ & No. & $\begin{array}{l}\text { Per } \\
\text { cent. }\end{array}$ \\
\hline 58 & 6 & $10 \cdot 3$ & 245 & 20 & $8 \cdot 2$ & 70 & 4 & $5 \cdot 7$ & 777 & 75 & $9 \cdot 7$ & 138 & 5 & $3 \cdot 6$ & 25 & 1 & $4 \cdot 0$ \\
\hline 78 & 18 & $23 \cdot 1$ & 283 & 72 & $25 \cdot 4$ & 87 & 22 & $25 \cdot 3$ & 755 & 176 & $23 \cdot 3$ & 110 & 8 & $7 \cdot 3$ & 42 & 4 & $9 \cdot 5$ \\
\hline 116 & 57 & $49 \cdot 1$ & 226 & 101 & $44 \cdot 7$ & 59 & 23 & $39 \cdot 0$ & 610 & 261 & $42 \cdot 8$ & 102 & 29 & $28 \cdot 4$ & 35 & 10 & $28 \cdot 6$ \\
\hline 60 & 44 & $73 \cdot 3$ & 52 & 30 & $57 \cdot 7$ & 15 & 9 & $60 \cdot 0$ & 237 & 146 & $61 \cdot 6$ & 42 & 23 & $54 \cdot 8$ & 19 & 9 & $47 \cdot 4$ \\
\hline
\end{tabular}

* Excluding Lothians Colliery.

height. After due allowance had been made for age and sitting height, it was found that the F.E.V. of the smokers was still significantly lower than that of the non-smokers, the average difference being of the order of 0.1 litre. The results for all three collieries together are summarized in Table VIII. There was no evidence of any systematic relationship between age and the difference in F.E.V. between smokers and non-smokers for men less than 50 years old. Amongst the oldest members of the population the difference between smokers and non-smokers was appreciably greater than amongst the remainder of the population. This may, however, be associated with retirement amongst the older men, who thereby form a more highly selected population than the younger age groups.

\section{TABLE VIII}

AVERAGE F.E.V.1 sec, (LITRES) OF SMOKERS AND NONSMOKERS BY AGE SHOWING EFFECT OF CORRECTION FOR SITTING HEIGHT

\begin{tabular}{|c|c|c|c|c|c|c|}
\hline \multirow{2}{*}{$\underset{\substack{\text { Group } \\
\text { Age }}}{\text { Aroup }}$} & \multicolumn{3}{|c|}{$\begin{array}{l}\text { Before Correction for } \\
\text { Sitting Height }\end{array}$} & \multicolumn{3}{|c|}{$\begin{array}{l}\text { After Correction for } \\
\text { Sitting Height }\end{array}$} \\
\hline & $\begin{array}{l}\text { Non- } \\
\text { smokers }\end{array}$ & Smokers & $\begin{array}{c}\text { Dif- } \\
\text { ference }\end{array}$ & $\underset{\text { smokers }}{\text { Non- }}$ & Smokers & $\begin{array}{l}\text { Dif- } \\
\text { ference }\end{array}$ \\
\hline $\begin{array}{c}\text { Under } 21 \\
21-30 \\
31-40 \\
41-50 \\
51-60 \\
\text { Over } 60\end{array}$ & $\begin{array}{l}4 \cdot 00 \\
3.96 \\
3.46 \\
3.03 \\
2.55 \\
2.24\end{array}$ & $\begin{array}{l}3 \cdot 81 \\
3 \cdot 84 \\
3 \cdot 40 \\
2 \cdot 92 \\
2 \cdot 42 \\
2 \cdot 02\end{array}$ & $\begin{array}{l}0 \cdot 19 \\
0 \cdot 12 \\
0 \cdot 06 \\
0 \cdot 11 \\
0 \cdot 13 \\
0 \cdot 22\end{array}$ & $\begin{array}{l}4 \cdot 09 \\
3 \cdot 86 \\
3 \cdot 44 \\
3 \cdot 04 \\
2 \cdot 71 \\
2 \cdot 38\end{array}$ & $\begin{array}{l}3 \cdot 96 \\
3 \cdot 77 \\
3 \cdot 38 \\
2 \cdot 96 \\
2 \cdot 56 \\
2 \cdot 21\end{array}$ & $\begin{array}{l}0.13 \\
0.09 \\
0.06 \\
0.08 \\
0.15 \\
0.17\end{array}$ \\
\hline
\end{tabular}

\section{Radiological PNeumoconiosis}

As the numbers of men assigned to the higher categories of pneumoconiosis at the three collieries are small, the prevalence of pneumoconiosis has been expressed in terms of only two classes-Category 0 and Category 1 or more. Details of the relationship between radiological pneumoconiosis and smoking habits are given in Table IX (overleaf). In general, there is no consistent difference between the prevalence of pneumoconiosis in smokers and non-smokers in the various age groups, but for both smokers and non-smokers it tends to be rather lower than for ex-smokers. When the smokers are considered separately, the amount of tobacco consumed by the younger men bears no consistent relationship to the prevalence of penumoconiosis. For men more than 50 years old, however, the prevalence is considerably lower amongst those who smoke most than amongst those who smoke least. There is no consistent difference between the prevalence of pneumoconiosis in the various age groups amongst the three smoking types.

\section{Discussion}

The information about smoking habits quoted in this paper is based on four short questions forming part of the respiratory symptoms questionnaire which is asked of each man during his medical examination. The results obtained were fairly consistent with those reported in other inquiries, and it is considered that they probably provide a valid measure of the true situation. In comparison with the figures given by Todd (1957) for all males in the United Kingdom, the mining populations under consideration included a higher proportion of men smoking cigarettes only and a lower proportion of 
PREVALENCE OF CATEGORY 1 OR MORE PNEUMOCONIOSF

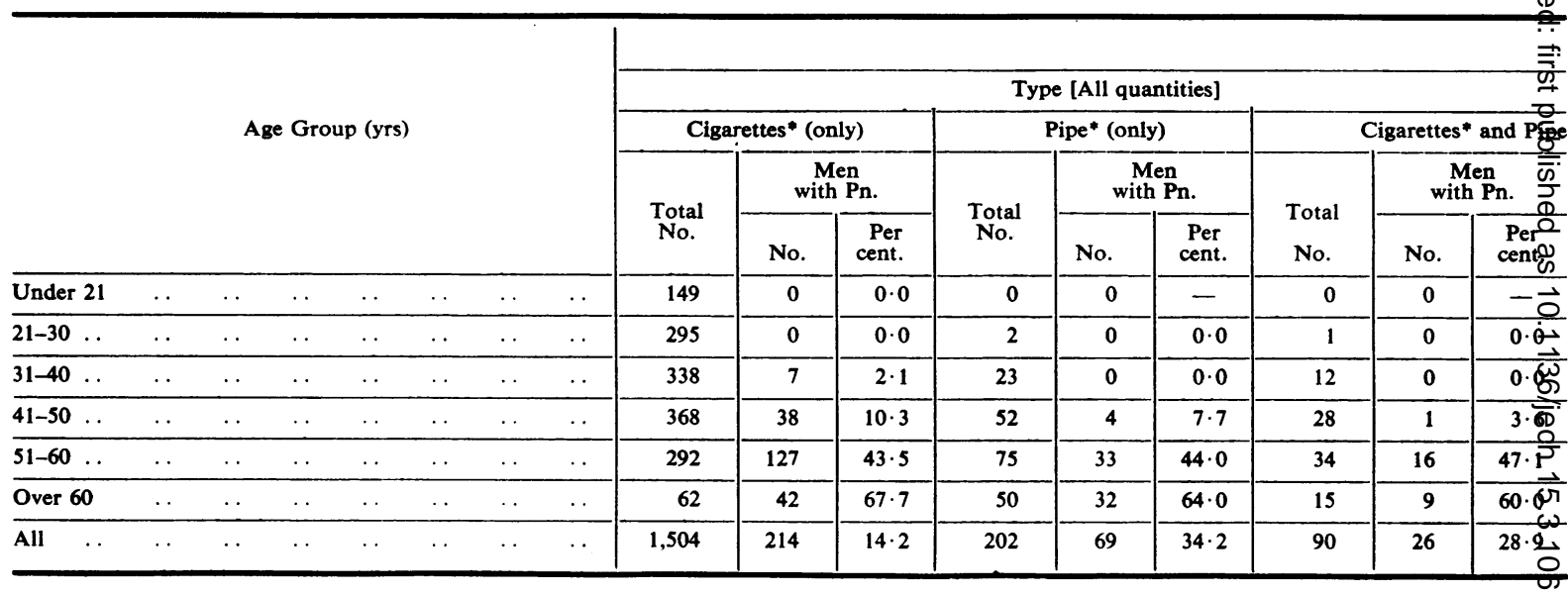

men smoking both cigarettes and pipe. The total consumption of tobacco by the smokers was slightly below the national average. This is not surprising, as the underground workers amongst the men under observation were not allowed to smoke at their place of employment.

At each colliery the prevalence of respiratory symptoms, as judged by the specified combination of positive answers to questions about cough, phlegm, etc., was found to be appreciably higher amongst the smokers than that amongst the non-smokers in all age groups. The tendency amongst the younger men for the difference between smokers and non-smokers to increase with age (Table VI) suggests that there is a direct association between smoking and respiratory symptoms. The differences in mean weights between the two groups also increased with age (Table IV), the smokers being lighter.

On the other hand, although there was a significant difference between smokers and non-smokers as regards sitting height (Table $\mathrm{V}$ ), the difference did not increase systematically with age. This suggests that the difference here is more likely to be due to a population selection effect than to a direct association with smoking. Thus, although the men who smoked most of all were comparable in height with the non-smokers, the average smoker was shorter. Similarly, the lowering of forced expiratory volume recorded for smokers, even after correction for height, remains reasonably uniform with age up to about 50 years (Table VIII). This also suggests a population selection effect rather than an effect due to smoking, which would be expected to increase with prolongation of the habit. The possibility that smokers are a self-selected group is consistent with the findings of Eysenck, Tarrant, Woolf, and England (1960), who demonstrated differences in certain personality traits between smokers and non-smokers which they attributed to genotypic differences. There is, however, a possible alternative explanation in that smoking in youth might retard physical development, especially ventilatory function (the majority of the men classed as smokers probably started smoking in their youth), whereas once growth has been completed smoking has no further effect.

The average difference in F.E.V. between smokers and non-smokers in the population examined was 0.1 litre, or about 3 per cent., after allowance had been made for sitting height and age. Comparison of this result with those of other workers is complicated by several factors, such as variations in the method of measuring ventilatory capacity, in the definition of "non-smokers", and in age distribution and smoking habits amongst the various populations examined. For example, most other investigators have dealt with smaller numbers, especially of non-smokers, and have reported the mean indirect maximum breathing capacity as their measure of ventilatory capacity, frequently using the F.E.V. $0.75 \mathrm{sec}$. as the basis of calculation. They have also usually refrained from making allowance for height. However, bearing these differences in mind, it is possible to compare some results in terms of the percentage lowering of ventilatory capacity, rather than of the absolute lowering, associated with smoking. Thus Olsen and Gilson (1960), in a population of male non-miners aged 55 to 64 years in Bornholm, found a difference of 14 per cent. $(106 \cdot 2$ to $91 \cdot 11 . / \mathrm{min}$.) in the mean 
IX

(PN.) BY SMOKING HABITS AND AGE

\begin{tabular}{|c|c|c|c|c|c|c|c|c|c|c|c|c|c|c|c|c|c|}
\hline \multicolumn{12}{|c|}{ Smokers } & \multirow{2}{*}{\multicolumn{3}{|c|}{ Non-Smokers }} & \multirow{2}{*}{\multicolumn{3}{|c|}{ Ex-Smokers }} \\
\hline \multicolumn{3}{|c|}{$1-10^{*}$} & \multicolumn{3}{|c|}{$11-20^{*}$} & \multicolumn{3}{|c|}{ Over $20^{*}$} & \multicolumn{3}{|c|}{ All Smokers } & & & & & & \\
\hline $\begin{array}{l}\text { Total } \\
\text { No. }\end{array}$ & No. & $\begin{array}{c}\text { Per } \\
\text { cent. }\end{array}$ & $\begin{array}{c}\text { Total } \\
\text { No. }\end{array}$ & No. & $\begin{array}{c}\text { Per } \\
\text { cent. }\end{array}$ & $\begin{array}{l}\text { Total } \\
\text { No. }\end{array}$ & No. & $\begin{array}{c}\text { Per } \\
\text { cent. }\end{array}$ & $\begin{array}{c}\text { Total } \\
\text { No. }\end{array}$ & No. & $\begin{array}{c}\text { Per } \\
\text { cent. }\end{array}$ & $\begin{array}{l}\text { Total } \\
\text { No. }\end{array}$ & No. & $\begin{array}{c}\text { Per } \\
\text { cent. }\end{array}$ & $\begin{array}{c}\text { Total } \\
\text { No. }\end{array}$ & No. & $\begin{array}{c}\text { Per } \\
\text { cent. }\end{array}$ \\
\hline 58 & 0 & 0.0 & 245 & 6 & $2 \cdot 4$ & 70 & 1 & 1.4 & 777 & 14 & $1 \cdot 8$ & 138 & 0 & 0.0 & 25 & 1 & $4 \cdot 0$ \\
\hline 78 & 6 & $7 \cdot 7$ & 283 & 26 & $9 \cdot 2$ & 87 & 11 & $12 \cdot 6$ & 755 & 62 & $8 \cdot 2$ & 110 & 10 & $9 \cdot 1$ & 42 & 4 & $9 \cdot 5$ \\
\hline 116 & 53 & $45 \cdot 7$ & 226 & 99 & $43 \cdot 8$ & 59 & 24 & $40 \cdot 7$ & 610 & 235 & $38 \cdot 5$ & 102 & 32 & $31 \cdot 4$ & 35 & 16 & $45 \cdot 7$ \\
\hline 60 & 40 & $66 \cdot 7$ & 52 & 35 & $67 \cdot 3$ & 15 & 8 & $53 \cdot 3$ & 237 & 131 & $55 \cdot 3$ & 42 & 29 & $69 \cdot 0$ & 19 & 9 & $47 \cdot 4$ \\
\hline
\end{tabular}

- Excluding Lothians Colliery.

indirect M.B.C. between 29 non-smokers and 13 men who smoked cigarettes only (average consumption $12 \mathrm{~g}$./day). Fletcher and others (1959), in their population of London postmen aged 40 to 59 years, found differences between eight non-smokers (mean indirect M.B.C., standardized to age $40,132 \cdot 8$ 1./min.), 87 smokers with a tobacco consumption of 1 to $14 \mathrm{~g}$./day (110.9 1./min.), and 37 smokers with a consumption of $15 \mathrm{~g}$. or more/day (104.3 1./min.), corresponding to a 17 per cent. drop in ventilatory capacity for the "light" smokers and of 21 per cent. for the "heavy" smokers. Higgins (1959), studying a random selection of 734 men aged 25-64 years, including non-miners as well as miners and exminers in urban and rural populations, reported a weighted difference of $91 . / \mathrm{min}$. (about 9 per cent.) between non-smoker and smokers, which was not due to small differences in the age distributions between the two groups. All these results show higher percentage differences between smokers and nonsmokers than those summarized in Table VIII (even before correcting for height). It might therefore appear that smoking is associated with a smaller reduction in ventilatory capacity amongst coalminers than amongst non-miners. This is not impossible, when it is remembered that the majority of coalminers are employed underground, where they are not permitted to smoke. This means that their smoking is done during their leisure hours, and not when they are hard at work. It is, of course, impossible to investigate this factor using the data presented here, and relatively little information has been published in the literature. Higgins (1959) has examined comparatively small groups of men and finds, for example, a difference between non-smokers and smokers of about 10 per cent. (100 to $90 \mathrm{l}$./min.) for non-miners aged 55 to 64 , compared with about 10 per cent. for miners (including ex-miners) without radiological pneumoconiosis and 20 per cent. for miners with simple pneumoconiosis. In the 25 to 34-year age group, his reported differences are about 8 per cent. for non-miners (in the Rhondda Fach), 15 per cent. for miners (including ex-miners) with Category 0 pneumoconiosis, and -10 per cent. for miners with Category 3 pneumoconiosis. For a corresponding group of non-miners aged 35 to 54 years, the value is about 20 per cent. The variations in these figures, both amongst themselves and in comparison with those quoted in Table VIII, are probably due to the small numbers of non-smokers in the various groups. This precludes the drawing of definite conclusions about the possible difference in the effect of smoking on ventilatory function in coalminers and non-miners. However, the subject is of considerable interest and worthy of further study.

It is interesting to note that, although differences in physique and ventilatory function have been found between smokers and non-smokers, the results obtained for the smokers show relatively little variation with the amount of tobacco currently consumed. Todd and Laws (1958) have observed that there may be considerable variations in individual smoking habits even within a short space of time, and they suggest that figures for the current consumption of tobacco by smokers cannot reasonably be extended to the whole of their past history. This conclusion is supported by the absence in these results, as in those of Higgins (1959), of any 
consistent relation between physique or ventilatory function and current consumption of tobacco. The only appreciable difference between the men smoking cigarettes only, pipe only, and cigarettes and pipe was noted in connexion with weight, which was considerably lower amongst the cigarette smokers.

The prevalence of pneumoconiosis tends to be higher amongst ex-smokers than amongst smokers and non-smokers, except in the oldest age group. Amongst smokers of 50 years and above, the prevalence of pneumoconiosis is lowest amongst the men who smoke the most and highest amongst the men who smoke the least. Both these effects might be due to a tendency for the men with pneumoconiosis to reduce their tobacco consumption.

\section{SUMmary}

The relation between smoking habits and physique, respiratory symptoms, ventilatory function, and radiological pneumoconiosis amongst the underground and surface workers at three Scottish collieries has been investigated, using data obtained during the medical surveys carried out by the National Coal Board's Pneumoconiosis Field Research. In general, the information obtained about current smoking habits follows a similar pattern to that reported on other recent surveys, although the observed proportion of smokers was slightly greater and the total consumption of tobacco by smokers was slightly less than the average recorded in a recent survey of males on a national basis. When the relation between physique and smoking habits was considered, it was found that in all age groups the non-smokers were, on average, taller and heavier than the smokers. The prevalence of respiratory symptoms amongst the non-smokers was appreciably lower than that amongst smokers of the same age. The ventilatory function (as measured by the F.E.V.1 sec.) of the non-smokers in all age groups was found to be significantly higher than that of the smokers, even when account was taken of differences in physique and age. In contrast to the differences between smokers and non-smokers, no consistent relationship was recorded between current consumption of tobacco and physique, respiratory symptoms, or ventilatory function amongst the smokers.

Some evidence was found which was consistent with a tendency for men with pneumoconiosis to reduce their tobacco consumption.
This paper is published by permission of the National Coal Board, who are not necessarily committed to the views expressed. The work forms part of the Board's Pneumoconiosis Field Research. Our thanks are due to Dr. J. M. Rogan (Chief Medical Officer, National Coal Board), under whose direction this work was carried out, to Drs. S. Rae and P. J. Chapman, who read the films, and to Mr. D. Hicks for invaluable discussions and advice.

\section{REFERENCES}

Abbott, O. A., Hopkins, W. A., Van Fleit, W. E., and Robinson, J. S. (1953). Thorax, 8, 116.

Ashford, J. R., Forwell, G. D., and Routledge, R. (1960). Brit. J. industr. Med., 17, 114.

Bickerman, H. A., and Barach, A. L. (1954). J. Lab. clin. Med., 43, 455.

Brown, R. G., McKeown, T., and Whitfield, A. G. W. (1957). Brit. J. prev. soc. Med., 11, 162.

Carpenter, R. G., Cochrane, A. L., Gilson, J. C., and Higgins, I. T. T. (1956). Brit. J. industr. Med., 13, 166. Clifton, M. (1956). Trans. Ass. industr. med. Offrs, 6, 66. Doll, R., and Hill, A. B. (1950). Brit. med. J., 2, 739

Eich, R. H., Gilbert, R., and Auchincloss, J. H. (1957). Amer. Rev. Tuberc., 76, 22.

Eysenck, H. J., Tarrant, M., Woolf, M., and England, L. (1960). Brit. med. J., 1, 1456.

Fay, J. W. J. (1957). Nature (Lond.), 180, 309.

and Rae, S. (1959). Ann. occup. Hyg., 1, 149.

Fletcher, C. M., Elmes, P. C., Fairbairn, A. S., and Wood, C. H. (1959). Brit. med. J., 2, 257.

Franklin, W. (1958). J. clin. Invest., 37, 895.

Gaensler, E. A. (1951). Amer. Rev. Tuberc., 64, 256.

Higgins, I. T. T. (1959). Brit. med. J., 1, 325.

, Cochrane, A. L., Gilson, J. C. and Wood, C. H. (1959). Brit. J. industr. Med., 16, 255.

, Oldham, P. D., Cochrane, A. L. and Gilson, J. C. (1956). Brit. med. J., $2,904$.

International Labour Office, Geneva (1953). "Proceedings of the 3rd International Conference of Experts on Pneumoconiosis". Sydney, 1950.

Ogilvie, A. G., and Newell, D. J. (1957). "Chronic Bronchitis in Newcastle-upon-Tyne". Livingstone, Edinburgh and London.

Olsen, H. C., and Gilson, J. C. (1960). Brit. med. J., $1,450$.

Palmer, K. N. V. (1954), Ibid., 1, 1473.

Rae, S. (1960). Private communication.

Rogan, J., Ashford, J. R., Chapman, P. J., Duffield, D. P., Fay, J. W. J., and Rae, S. (1961). Brit. med.J., 1, 1337.

Todd, G. F. (1957). Tobacco Manufacturers' Standing Committee Research Papers. No. 1, "Statistics of Smoking".

and Laws, J. T. (1958). Tobacco Manufacturers' Standing Committee Research Papers, No. 2, "The Reliability of Statements about Smoking Habits". 


\section{APPENDIX}

\section{Respiratory Symptoms Questionnaire}

\section{PREAMble}

I am going to ask you some questions about your chest, about cough and spit, for example. Please try and answer "yes" or "no", but if you do not understand a question then ask me about it.

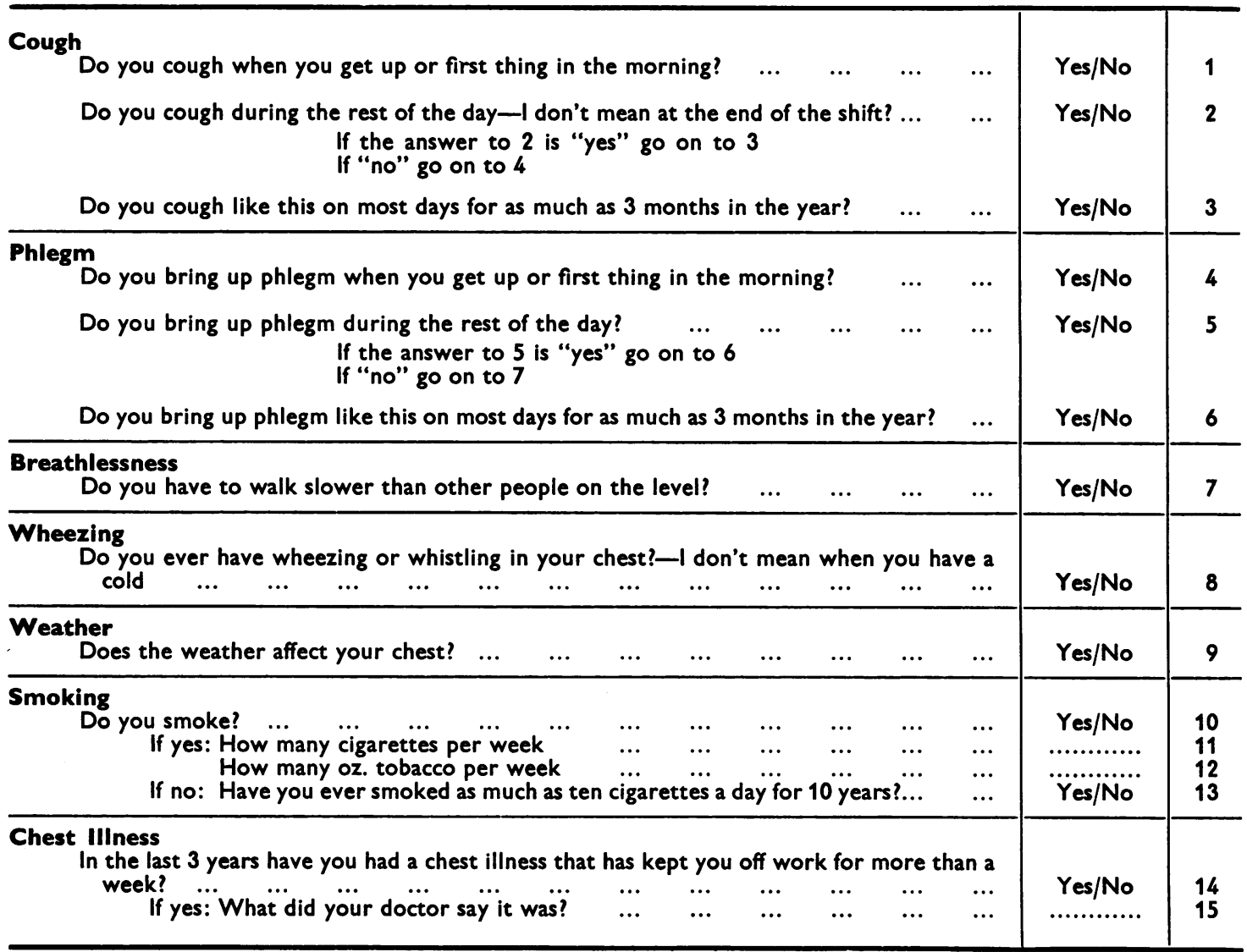

RESPIRATORY SYMPTOMS TO BE DIAGNOSED IF POSITIVE ANSWERS ARE GIVEN TO:

(a) QUESTIONS 3 OR 6 AND 7 OR 8 OR 9 OR 14

OR

(b) QUESTIONS 8 AND 9 